\title{
Civic Education: Fostering Global Citizenship among Indonesian Students
}

\author{
Zaky Farid Luthfi ${ }^{1}$, Henni Muchtar ${ }^{2}$, Prayoga Bestari ${ }^{3}$, Atri Waldi ${ }^{4}$, and Wibowo Heru \\ Prasetiyo ${ }^{5}$, \\ 1, 2, 4, Universitas Negeri Padang \\ ${ }^{3}$ Universitas Pendidikan Indonesia \\ ${ }^{5}$ Universitas Muhamadiyah Surakarta \\ aky.farid@fis.unp.ac.id
}

\begin{abstract}
This study aims to analyze the curriculum content of Civic Education in Indonesia and its ability to prepare students for global citizenship. Global issues such as global economy, international conflicts, interdependency, climate changes, and natural resource conflicts, create yet other issues which can be resolved at best with a satisfactory education system. Civic Education as a multidimensional education aims to foster global citizenship among Indonesian students through the topics included in the curriculum. Curriculum as part of education system contributed to prapare young citizens in future to face new chalnges. This study employed qualitative method with content analysis technique. All of topics that related with Global Citizenship topics collect and analyze with refereces. The curriculum of Civic Education in Indonesia contains five main topics: human rights, global governance, diversity, national security, and interdependency.. These contents of Civic Education promote students who have global knowledges, yet hold firm to the virtues of Indonesia.
\end{abstract}

Keywords: global citizenship, students, civic education

\section{INTRODUCTION}

Global Citizenship Education (GCE) has been the discussion and the central issue addressed since the beginning of the $21^{\text {st }}$ century by the expert scholars of Civic Education. There are three reasons this particular issue is of great significance and intriguing to be analyzed. Firstly, the increasing intercultural communication and human mobility which create a new order in the economic, social, and cultural fields [1], [2]. Each individual should be aware of the impact of cultural contact thereby can adapt to other cultures and minimize cultural conflict. Secondly, global issues such as natural resource scarcity, global warming, the increment of global interdependence, international conflicts, terrorism, global economic competition, and the rapid development of information technology [3]-[5], need to be explored by every young citizen in order to have a broad knowledge and understanding of the matter and take an active role for a better world. Thirdly, the emergence of negative impacts of globalization which take issuewith our local values. Globalization has challenged the power of the implementation of national identity and ruined Indonesia's national value [6]. The way Indonesian youth are more interested in modern culture and tend to disregard the national 
culture is the big picture of how globalization has brought massive change to the values adopted by students in Indonesia.

Civic Education, in fact, has a role in encouraging students to have a global perspective that is the ability to comprehend a problem from different points of view [7]. GCE encourages students to have a bond in the community of global citizens, a sense of responsibility, global competitiveness, and a willingness to integrate with social change [8]. However, the role of Civic Education in Indonesia has not been the utmost, which is indicated by two facts. First, Indonesia ranks second last in civic knowledge out of 32 countries surveyed [9]. This survey measured students' understanding of general topics concerning civic knowledge such as the functions of government, democracy, the role of political parties and civil society involvement. Second, students' partaking in responding to local, national or global civic issues.

To answer challenges of globalization, Japan has embedded a special theme regarding globalization in Civic Education. It is contained in "international society and the challenges" which covers topics like defense, security, international relationship, diversity, and international contribution [10]. Civic Education in Japan has encouraged young citizens so that they are able to adapt to the rapid global changes[10], [11]. On the other hand, GCE in South Korea raises issues such as poverty and global equality [8] as an attempt to position the country as the "savior" for other countries in need.

To response about the challenge, this study aims to explore the curriculum content of Civic Education in Indonesia by comparing several indicators developed by UNESCO and Oxfam. This works toward discovering to what degree the curriculum of Civic Education has motivated young citizens to be global citizens.

\section{METHOD}

This study employed qualitative approach with document analysis method. Document analysis is a systematic procedure to review or evaluate documents, both printed and electronic [12], [13]. The first step in the process was to collect the main source of high school curriculum and student textbooks. A coding was then planned out by setting the indicators that refer to Oxfam and UNESCO guide of global citizenship. Besides, the document analysis was also supported by a series of interviews with expert scholars of Civic Education and education curriculum experts to enhance the result of the analysis. The object of the study was Civic Education 2013 High School Curriculum.

\section{RESULT AND DISCUSSION}

Civic Education had been updated in 2013 with several significant changes. Some revisions made were a balanced division of components into civic knowledge, civic skills, and civic disposition. The division of these components clarifies the purpose and direction of Civic Education to a greater extent in the hope of being thoroughly taught in its application. At the same time, a finding indicates that the curriculum of Civic Education introduces global citizenship knowledge in the basic competencies as described in Table 1. 
Table 1. Global Citizenship Knowledge

\begin{tabular}{|c|c|c|}
\hline $\begin{array}{l}\text { Topic in Global } \\
\text { Citizenship } \\
\text { Knowledge }\end{array}$ & Description of Topic & Basic Competency \\
\hline $\begin{array}{l}\text { Equality and social } \\
\text { justice }\end{array}$ & $\begin{array}{l}\text { - Challenges and dilemmas in } \\
\text { upholding justice and equality } \\
\text { Ability to gain a broader } \\
\text { perspectives on problem } \\
\text { respecting justice and the } \\
\text { solution }\end{array}$ & $\begin{array}{l}\text { - Practice and protection of the } \\
\text { laws } \\
\text { - Understand the judicial } \\
\text { process }\end{array}$ \\
\hline
\end{tabular}

\begin{tabular}{lllll}
\hline $\begin{array}{l}\text { Identity } \\
\text { diversity }\end{array}$ & and $\bullet$ & $\begin{array}{l}\text { Students are able to recognize } \\
\text { their identity as Indonesian }\end{array}$ & $\begin{array}{l}\text { Understand the main points } \\
\text { implied in the Preamble of the } \\
\text { Students identify cultural } \\
\text { diversity and critically analyze } \\
\text { the impact of the diversity }\end{array}$ & $\begin{array}{l}1945 \text { Constitution } \\
\text { Analyze the indicators of } \\
\text { national security threat } \\
\text { Understand the importance of } \\
\text { national consciousness }\end{array}$ \\
\hline $\begin{array}{l}\text { Globalization and } \\
\text { global } \\
\text { interdependence }\end{array}$ & $\begin{array}{l}\text { Understand the impact of } \\
\text { globalization } \\
\text { Globalization benefits and } \\
\text { challenges for government and } \\
\text { society }\end{array}$ & $\begin{array}{l}\text { Evaluate Indonesia's role in } \\
\text { international affair }\end{array}$ \\
\hline
\end{tabular}

\begin{tabular}{|c|c|c|c|}
\hline Human rights & & $\begin{array}{l}\text { History and philosophy of } \\
\text { human rights } \\
\text { Globalization challenges } \\
\text { encountered by government } \\
\text { Universality in human rights }\end{array}$ & $\begin{array}{l}\text { - Analyze cases of human } \\
\text { rights violation } \\
\text { Analyze cases of human } \\
\text { rights violation in order to } \\
\text { protect, promote, and fulfill } \\
\text { human rights }\end{array}$ \\
\hline
\end{tabular}

\begin{tabular}{lcll}
\hline $\begin{array}{l}\text { Authority and } \begin{array}{l}\text { How individual and group, } \\
\text { government }\end{array} \\
\text { public or private sector, } \\
\text { contribute to global government }\end{array}$ & $\begin{array}{l}\text { Understand the structural and } \\
\text { functional relationships } \\
\text { between national and local } \\
\text { government. }\end{array}$ \\
& $\begin{array}{l}\text { Analyze the dynamic of } \\
\text { administering a country }\end{array}$ \\
\hline
\end{tabular}

From Table 1, equality and justice as the topics for discussion included in Civic Education in Indonesia is based on the philosophical theory of the Indonesian state, Pancasila. The academic subject has students to understand justice in contexts by guiding them with subject matters of judicial process and protection of the law. Students acquire a knowledge of judicial systems in every level, from national through international system.

As a multicultural country, Civic Education in Indonesia equips students with an awareness of the assortment of religions, ethnicity, races, and cultures in Indonesia. The term 
"diversity of unity" is introduced from the idea of Bhinneka Tunggal Ika. Students are prompted to inspect the challenges, threats, and obstacles to building national integration. Cultural diversity through Indonesia's multicultural perspective is manifested in the slogan "Bhineka Tunggal Ika". The profound meaning it holds needs to be preserved towards Indonesia's continuance as a nation in the future.

Students examine some globalization issues by evaluating Indonesia's role in international affairs. Civic Education is responsible in stimulating comprehension of global citizenship which covers national welfare issues and how to enhance competitiveness in global competence [1]. Furthermore, students are invited to discuss benefits and challenges of globalization, especially for building a society that more prepared and responsible to overcome their social problems.

Human rights become the central issue which are profoundly analyzed in Civic Education. This issue is presented as a campaign of universal values such as humanity, tolerance, and respect to other truths. Teachers should make learning activities by analyzing several cases of human rights violations.

Civic education in Indonesia contains heavy legal and governance materials which are related to preserve young citizens' understanding about their duty and rights. The elements provided an understanding of structural and functional of the Indonesian government. The students studied relationships between national and local government in order to analyze the dynamic of administering a country.

Globalization era has led a life that requires students to change their perspective about how perceive themselves and others. It demands that every nation and country to be willing to see global point of view. If it were otherwise, it would cost them an isolation. No country or nation is possible to conceal or isolate themselves from the impact of globalization. It refers to various absurd phenomenon, yet generally illustrated in a single and economical term which pictures the development phase of evolutionary society, inevitable, and unalterable (Matthews $\&$ Sidhub, 2005). If we criticize, the media on television and the internet often use the word "the best in the world" which also one form of marketing about globalization, even though it is called "shallow globalization"[14], [15].

Based on Table 2, Civic Education is preparing students with a set of global citizens' skill. It is illustrated by the content of personal attitudes and skills which needed to live together. Empathy is required as a moral basis to establish equal interactions with the others, considering Indonesia as cultural diversity. Students are expected to express their feelings as their rights such as freedom to speak and giving opinions in public sphere. To enhance this ability, the teachers give opportunities in learning activities within peer group learning, debate, and presentations by improving public speaking skills.

Table 2. Global Citizens skills

\begin{tabular}{|c|c|c|}
\hline $\begin{array}{c}\text { Topic in Global } \\
\text { Citizenship Education }\end{array}$ & Description of Topic & $\begin{array}{l}\text { Formulation in Basic } \\
\text { Competency }\end{array}$ \\
\hline Empathy & $\begin{array}{l}\text { - Show empathy for } \\
\text { what is being felt }\end{array}$ & $\begin{array}{l}\text { Interact with peers and } \\
\text { others which develops on } \\
\text { mutual respect for diversity } \\
\text { in ethnicity, religion, race, } \\
\text { culture and gender }\end{array}$ \\
\hline Communication skill & $\begin{array}{lr}\begin{array}{l}\text { Present a global } \\
\text { issue } \\
\text { communicate }\end{array} & \text { with } \\
\end{array}$ & $\begin{array}{l}\text { - Present cases of human } \\
\text { rights violations in order to } \\
\text { protect and promote human }\end{array}$ \\
\hline
\end{tabular}




peers in the rights with the connection to
classroom the principles of Pancasila in

- Students listen and life as society and nation comment on their $\bullet \quad$ Present the result of analysis peers' opinion. of legal and judicial system in Indonesia

Globalization refers to the formation of a world system, in contrast to internationalization which presupposes the states as an important unit. Globalization covers finance and trade, communication and information technology; migration and tourism, global community, linguistic, cultural, and ideological convergence. Although it does not exclude countries, it changes its state and potential[16]. Thus, the interdependence or dependence of life on this earth has led to an increase in the importance of mastering the science and professional skills of global citizens which is a condition in understanding global dimension of phenomena, politics, economics, and culture. When drawn from its historical root, intercultural tolerance and cosmopolitanism are the consequences of unexpected and unintentional European trade, capitalism, as well as colonialism growth[17]. The western world calls globalization as an inevitability whose existence is certain[18].

Every nation, both individuals and groups, is competing against competitors in all fields of life. In other words, globalization has demanded every global citizen to improve the quality of human resources to face competition since, in this era, only qualified human beings will survive or continue to exist. If we examine globalization, it cannot be separated from the global system issues. As a country, we must make connection throughout the world to a stage that was never predicted before.

There are more complex post-globalization relationships related to interdependence between nations. In 1977, two international relation students, Robert Keohane and Joseph Nye, reassessed the validity of the state-centric model and advocated new model that could more accurately represent the the reality of modern international communication and interaction. The new model, known as a complex interdependence model, has different view and interaction between subjects from state-centric model. The differences between these two models are shown as follows:
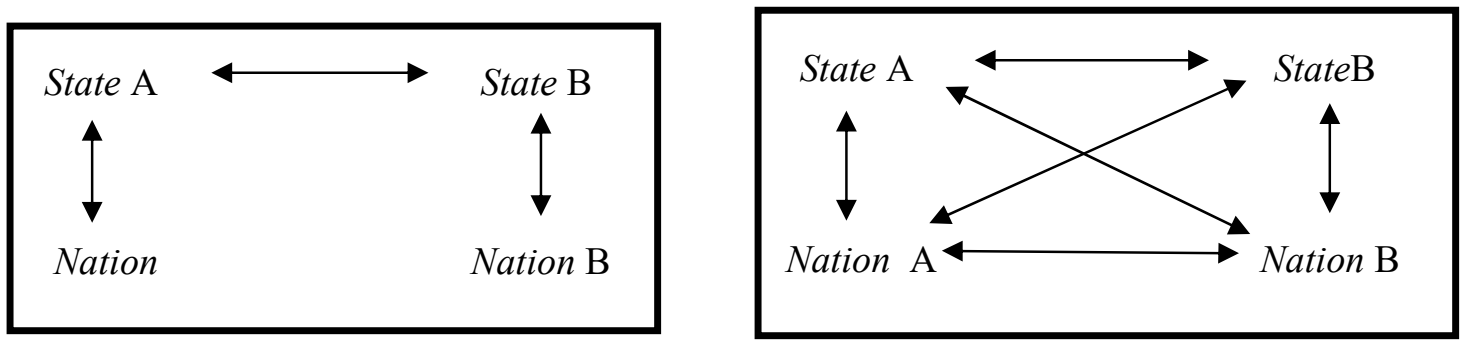

Figure 1. State-Centric Model dan complex interdependence model.

Figure 1 shows that in the state-centric model, both state A and B represent their own country (personal or group), as shown by the arrow. In addition, international interactions are shown by two-way communication arrows between state A and B. Since the exchange occurs 
at the state level, one can describe it as relation between countries, not international relations. This means that the communication and interdependence of the two countries are limited to formal diplomatic relations.

In contrast, complex interdependence model inherits the state-to-state communication channels, but is superior to the previous model because of its additional path. The complex interdependence model shows the interaction between country A and B (as well as country B and A), since modern countries use public diplomacy campaigns to convince foreign countries to approve their choises, goals, and means of policy.

The study of the global system is one of the topics that should be the content of the globalization topic. The relationship with every nation throughout the world has arrived at a stage that was never predicted. The interrelationships and interdependencies between nations are the result of our nation's participation in a system that is running in the world today which is often called as a global system. As we realize, the scope of interdependence has increased since the end of the Second World War. This change can be traced to advances in science and technology that seem to have diminished the world as well as changes in interaction between countries that have succeeded in forming United Nation (UN) international organization and stopping the imperialism and colonialism tradition. Since we are in the middle of a global interaction system, we also experience global dependence. All these systems certainly have the characteristics of interaction opportunity component and the rules of the game as well as its influence.

In addition to discussing the concept of globalization, global education in its content also contains global issues as actual sources of information for students. At least the characteristics of global issues and problems, namely the scope is transnational, problems can only be resolved by multilateral, conflicts involving all parties, and the conflicts are continuous and interrelated[7]. In a pedagogical context, global education is applied to intercultural relation and communication [20]. This means that global education has a role that is able to bridge or mediate so that students recognize the connection between cultures. There is an interesting proposal from global education efforts, namely the need for more important involvement with geopolitical knowledge and current issues[21]so as global education can be studied more deeply and interestingly [22].

\section{CONCLUSION}

Civic education in Indonesia has included global competences in its national curriculum. In the aspect of knowledge of citizenship, the topics covered include elements such as a legal protection, diversity and human rights. Diversity is the main issue emphasized, remembering that Indonesia is a pluralistic country with a diversity of tribes. Meanwhile, in the domain of citizenship, the topics studied were empathy, namely the principle of mutual respect, and respect for diversity in ethnicity, religion, race, culture, and gender. The next researcher is expected to be able to explore the implications at school.

\section{REFERENCES}

[1] P. Enslin, "Education for global citizenship: The cosmopolitan and the patriotic," Citizenship, Soc. Econ. Educ., vol. 10, no. 2\&3, pp. 93-100, 2011.

[2] P. W. Jones, "Globalisation and Internationalism : democratic prospects for world education,” Comp. Educ., no. July 2012, pp. 143-155, 2006.

[3] A. K. Agbaria, "The social studies education discourse community on globalization: Exploring the agenda of preparing citizens for the global age," J. Stud. Int. Educ., vol. 
15, no. 1, pp. 57-74, 2011.

[4] J. J. Cogan and B. J. Derricott, Citizenship for the 21st Century: An International Perspective on Education. Tokyo, 1998.

[5] M. Print and L. Dirk, "Teacher Pedagogy and Achieving Citizenship Competences In School," in Schools, Curriculum and Civic Education for Building Democratic Citizens, 2012, pp. 1-148.

[6] D. Budimansyah, Penguatan pendidikan kewarganegaraan untuk membangun karakter bangsa. Bandung: Widya Aksara Press, 2010.

[7] A. A. Wahab and Sapriya, Teori dan landasan pendidikan kewarganegaraan. Bandung: Alfabeta, 2010.

[8] H. S. Cho and J. Mosselson, "Neoliberal practices amidst social justice orientations: global citizenship education in South Korea," Compare, vol. 48, no. 6, pp. 861-878, 2018.

[9] W. Schulz, J. Ainley, J. Fraillon, D. Kerr, and B. Losito, ICCS 2009 International Report: Civic Knowledge, Attitudes, and Engagement among Lower-Secondary School Students in 38 Countries. 2010.

[10] C. Mori and I. Davies, "Citizenship education in civics textbooks in the Japanese junior high school curriculum," Asia Pacific J. Educ., vol. 35, no. 2, pp. 153-175, 2015.

[11] C. D. Hammond, "Internationalization, nationalism, and global competitiveness: a comparison of approaches to higher education in China and Japan," Asia Pacific Educ. Rev., vol. 17, no. 4, pp. 555-566, 2016.

[12] G. A. Bowen, "Document Analysis as a Qualitative Research Method," Qual. Res. J., vol. 9, no. 2, pp. 27-40, 2009.

[13] J. R. Fraenkel, N. E. Wallen, and H. H. Hyun, How to design and evaluate research in education. New York: McGraw-Hill Humanities/Social Sciences/Languages, 2011.

[14] J. Matthews, "International education and internationalisation are not the same as globalisation: Emerging issues for secondary schools," J. Stud. Int. Educ., vol. 6, no. 4, pp. 369-390, 2002.

[15] L. Cheung, E. Wong, P. K. Ng, and K. Wong, "Assessing the impact of globalisation: Lessons from Hong Kong," BIS Pap., no. 100i, 2018.

[16] S. Marginson, "After globalization: emerging politics of education," J. Educ. Policy, vol. 14, no. 1, pp. 19-31, 1999.

[17] X. Chen, A. L. Elliott, and S. Wang, "Cross-country Association of Press Freedom and LGBT freedom with prevalence of persons living with HIV: implication for global strategy against HIV/AIDS," Glob. Heal. Res. Policy, vol. 3, no. 1, p. 6, 2018.

[18] M. Henry, "Working with/against globalization in education," J. Educ. Policy, vol. 14, no. 1 , pp. 85-97, 1999

[19] H. Sadri and M. Flammia, "Using technology to prepare students for the challenges of global citizenship,” J. Syst. Cybern. Informatics, vol. 7, no. 5, pp. 66-71, 2009.

[20] M. Lorenzini, "From global knowledge to global civic engagement," J. Polit. Sci. Educ., vol. 9, no. 4, pp. 417-435, 2013.

[21] J. P. Myers, "Charting a democratic course for global citizenship education: Research directions and current challenges," Educ. Policy Anal. Arch. Anal $\backslash \backslash \mid i\}$ ticos Pol $\{|’|\}_{\}}$ticas Educ., vol. 24, pp. 1-19, 2016.

[22] K. Saddhono, "Integrating culture in Indonesian language learning for foreign speakers at Indonesian universities,” J. Lang. Lit., vol. 6, no. 2, 2015. 